\title{
O monge e o demônio etíope: raça e discretio nas Collationes Patrum de João Cassiano (426-428)
}

Bruno Uchoa Borgongino*

\section{RESUMO}

João Cassiano escreveu as Collationes Patrum entre os anos 426 e 428, num período em que já estava estabelecido num mosteiro nos arredores da cidade de Marselha, na Gália. Nesse documento, abordou diversos temas sobre a vida monástica, dentre eles, a virtude da discretio. João Cassiano incluiu também narrativas ilustrativas para seus argumentos, sendo que em algumas delas demônios em forma de etíopes instigavam os monges aos vícios - o que se alinhava aos discursos raciais que circulavam o contexto mediterrânico. O objetivo deste artigo é analisar as relaçóes entre os demônios em forma de etíopes e o conceito de discretio nas Collationes Patrum.

Palavras-chaves: raça; etíopes; discretio; monaquismo.

\section{The monk and the ethiopian demon: race and discretio in John Cassian's Collationes Patrum (426-428)}

\begin{abstract}
John Cassian wrote the Collationes Patrum between 426 and 428, at a time when he was already established in a monastery around the city of Marseille, in Gaul. In this document, he discussed several themes about monastic life, among them, the virtue of discretio. John Cassian also included illustrative narratives for his arguments. Some depicted demons in the form of Ethiopians instigating the monks to indulge in vice, which aligned with the racial discourses then circulating in the Mediterranean. The objective of this paper is to
\end{abstract}

DOI: http://dx.doi.org/10.1590/2237-101X02204704

Artigo recebido em 27 de agosto de 2020 e aceito para publicação em 9 de outubro de 2020.

* Professor da Universidade Federal de Pernambuco, Departamento de História, Recife/PE - Brasil. E-mail: uchoa88@gmail.com. ORCID: https://orcid.org/0000-0002-8354-1085. 
analyze the relationships between the Ethiopian demons and the concept of discretion in the Collationes Patrum.

Keywords: race; ethiopians; discretio; monasticism.

\section{El monje y el demonio etíope: raza y discretio en las Collationes Patrum de João Cassiano (426-428)}

\section{RESUMEN}

João Cassiano escribió las Collationes Patrum entre los años 426 y 428, en un periodo en el que ya estaba establecido en un monasterio en los alrededores de la ciudad de Marsella, en Galia. En ese documento, abordó diversos temas sobre la vida monástica, dentro de ellos, la virtud del discretio. João Cassiano incluyó también narrativas ilustrativas para sus argumentos, siendo que en algunas de ellas, demonios en forma de etíopes incitaban a los monjes al vicio- lo que se alineaba a los discursos raciales que circulaban el contexto mediterráneo. El objetivo de este artículo es analizar las relaciones entre los demonios en forma de etíopes y el concepto de discretio en las Collationes Patrum.

Palabras clave: raza; etíopes; discretio; monacato.

Em meados da década de 380, João Cassiano e Germano saíram do mosteiro de Belém, onde receberam sua formação monástica inicial. Nos anos subsequentes, circularam pelo Egito e pela Palestina, visitando comunidades e estabelecendo contato com ascetas proeminentes dessas regióes. Foi por volta do ano de 410 que Joáo Cassiano se estabeleceu definitivamente nas cercanias da cidade de Marselha, no sul da Gália, e escreveu documentos que sobreviveram até os nossos dias (STEWART, 1998, p. 3-12). ${ }^{1}$

Um dos materiais que produziu foram as Collationes Patrum (426-428), conjunto de 20 livros na forma de diálogos que, segundo alegava, reproduziriam fielmente os ensinamentos que recebeu dos Pais do Deserto. Cada um desses livros era dedicado a um aspecto da vida monacal, que era debatido de maneira a fornecer respaldo teórico às aspiraçôes político-eclesiásticas das facçôes clericais com as quais João Cassiano estava coligado - especialmente no que tange à legitimidade de determinadas formas de vivência monástica e de autoridade ascética. ${ }^{2}$

\footnotetext{
${ }^{1}$ Há estudos disponíveis que propóem uma reconstituição da trajetória de João Cassiano, tanto quanto é possível realizar a partir dos dados dispersos pela documentação preservada. Dentre esse material, indico Stewart (1998).

${ }^{2}$ Neste trabalho, consulto a versão do documento publicada pela Éditions du Cerf em que constam a edição crítica com o texto original em latim e a tradução para o francês. Para as citações diretas, recorro à tradução para o português lançada pela Subiaco, realizando, eventualmente, algumas correçóes pontuais. Esclareço,
} 
Dentre os temas abordados nas Coll., constava a virtude da discretio, ou seja, a aptidáo para a avaliação de pensamentos súbitos e para ação adequada ante eles. Além disso, foram narrados supostos casos de monges que foram atormentados por demônios, sendo algumas dessas figuras infernais retratadas como tendo a aparência de etíopes. Essas mençôes a etíopes demoníacos ocorreram em passagens em que a discretio desempenhava papel preponderante.

O objetivo do presente artigo consiste em avaliar as relaçóes estabelecidas por João Cassiano nas Coll. entre a caracterização dos demônios como etíopes e a noçáo de discretio. Neste trabalho, parto da polêmica premissa de que o monge marselhês escreveu num contexto mediterrânico em que já circulavam discursos raciais, inclusive nos meios monásticos. Para este fim, empreendo a investigação proposta em três etapas: primeiramente, avalio a aplicabilidade do conceito de raça para o estudo dos etíopes nos discursos sobre o monaquismo emergente; em seguida, exponho as reflexóes de João Cassiano a respeito da discretio; por fim, identifico e analiso as passagens das Coll. em que demônios se apresentam na forma de etíopes, avaliando as associaçóes existentes com o conceito de discretio.

\section{Raça, etíopes e monaquismo emergente}

No ano de 1970, Frank M. Snowden publicou Blacks in Antiquity: Ethiopians in Greco-Roman Experience. O livro apresentava um estudo sobre os encontros de gregos e romanos com negros provenientes da África, desde Homero até o governo de Justiniano. Embora pesquisadores já tivessem abordado a questão antes, ${ }^{3}$ o trabalho de Snowden empreendia pela primeira vez um levantamento exaustivo de dados num corpus documental ampliado, que contemplava literatura, numismática e arqueologia (SNOWDEN, 1970).

Das hipóteses postuladas por Snowden a partir de Blacks in Antiquity, a tese de que inexistiria preconceito de cor no mundo antigo foi a de maior repercussão. ${ }^{4}$ Segundo postulou, a representaçáo da negritude teria sido realizada como uma curiosidade científica e como contraste fisionômico em relaçáo aos grupos greco-romanos, não como meio de inferiorização. Os etíopes, designação então aplicada a todos os negros, eram enquadrados num discurso que opunham gregos e romanos aos não-gregos e não-romanos, numa contraposição em que outros grupos humanos estariam inseridos. No penúltimo capítulo, dedicado às atitudes do cristianismo antigo, Snowden argumentou que o preconceito de cor continuou ausente. A referência greco-romana do etíope como o mais negro e remoto dos homens

ainda, que a partir desse momento usarei a sigla Coll. para me referir às Collationes Patrum. As devidas referências dessas ediçôes constam na relação bibliográfica ao final do artigo.

${ }^{3}$ É o caso, por exemplo, do trabalho de Grace H. Beardsley (1922).

${ }^{4}$ Para um panorama sobre a recepção e os debates desencadeados pelo trabalho de Snowden, conferir Samuels (2013). 
era empregada pelos cristáos para afirmar a universalidade da fé, sem conotaçóes negativas (SNOWDEN, 1970, p. 2-14; 169-215).

As teses de Snowden estavam em consonância com uma ideia então em voga: a de que a hierarquização racial que supunha o negro como inferior consistiria num fenômeno moderno, atrelado ao colonialismo europeu, à massiva escravização africana, e aos saberes científicos de séculos recentes. ${ }^{5} \mathrm{O}$ próprio Snowden reconheceu que a tese da inexistência de conotaçóes negativas nas representaçôes raciais da Antiguidade já estava consolidada na época em que escrevia Blacks in Antiquity (SNOWDEN, 1970, p. 169). A partir de fins da década de 1990, diversos antiquistas e medievalistas contestaram tais premissas e a obra de Snowden, atestando a existência de discursos raciais anteriores à modernidade. ${ }^{6}$ Alinho-me a essa perspectiva historiográfica renovadora, defendendo a pertinência do conceito de "raça” para o estudo dos etíopes nos discursos produzidos na época de emergência do monaquismo cristão.

Para uma delimitação conceitual de "raça” aplicável a esse tipo de análise, não se deve recorrer às definiçôes tributárias das ciências biológicas, incabíveis para grupos humanos, mas às desenvolvidas pelas ciências sociais. Antônio Sérgio Alfredo Guimarães afirma que as ra-

\footnotetext{
${ }^{5}$ Alguns especialistas pontuaram os contextos históricos em que se produziu a ideia de ausência do pensamento racial antes da modernidade. Dench demonstrou que, entre fins do século XIX e início do XX, a abertura étnica nas estruturas da sociedade romana foi apontada como um dos motivos para o seu declínio. Tal perspectiva foi formulada num contexto de desconforto frente a um Império Romano percebido nos EUA e pelos impérios coloniais europeus como emblema de racionalidade e sucesso civilizacional; a mistura racial romana se transformou numa lembrança sobre os perigos da miscigenação. Dessa maneira, o "multiculturalismo" romano celebrado atualmente foi utilizado de maneiras nocivas no passado, inclusive na Itália de Mussolini (DENCH, 2005, p. 5-11). Numa análise dos discursos sobre o cristianismo primitivo, Buell argumentou que a imagem de um universalismo cristão originário que estaria para além das questôes raciais embasou reivindicaçôes por reformas antirracistas e antiescravistas na contemporaneidade, mas também pautou visóes antijudaicas e antissemitas (BUELL, 2001, p. 453-457). Heng analisou o mito da ausência de pensamento racial na Idade Média em seu The invention of race in the Middle Ages. De acordo com sua argumentação, a modernidade é posicionada simultaneamente como marco de uma ruptura temporal e de um novo momento na história, numa perspectiva teleológica que versa sobre a origem de um Ocidente único, excepcional e superior. Nessa narrativa histórica, a Idade Média seria situada à parte dos sistemas de significação da Idade Moderna, sendo assim isenta dos erros e atrocidades modernos e tendo seus próprios erros e atrocidades relevados como não-significativos - daí a exclusão do medievo dos estudos raciais (HENG, 2018, p. 20-24). Portanto, em concordância com as autoras, a ideia da não-relevância ou não-existência de discursos raciais antes da modernidade foi e ainda é manejada para fundamentar projetos excludentes no Ocidente.

${ }^{6}$ Entre os antiquistas, Benjamin Isaac foi pioneiro na análise da construção racial dos outros no mundo greco-romano, argumentando, inclusive, que na Antiguidade teria emergido um protorracismo que anteciparia o racismo moderno (ISAAC, 2004). Por parte dos medievalistas, Thomas Hahn empreendeu uma reflexão teórica que fomentou o debate sobre a questão (HAHN, 2001). Trabalhos posteriores em ambas as áreas endossaram os argumentos favoráveis à tese de que raça já operava antes da modernidade, entre os quais destaco Bartlett (2001), Heng (2018) e Buell (2001). Alguns que realizaram sínteses da história do discurso racial e do racismo incluíram capítulos sobre períodos anteriores ao século XVI (BETHENCOURT, 2018; FREDRICKSON, 2002), o que indicaria a validade das contribuiçóes de antiquistas e medievalistas aos estudos sobre raça. Todavia, se por um lado há a tendência de se reconhecer a pertinência do conceito de raça para casos anteriores à modernidade, por outro a existência de racismo prossegue como objeto de divergência. Em consonância com o objetivo deste artigo, não me posicionarei frente a esse debate.
} 
ças são efeitos de discursos sobre origens e a essência de um grupo e de transmissão de traços fisionômicos, intelectuais e morais entre gerações (GUIMARÃES, 2003). Achille Mbembe argumenta que a raça seria uma ficção útil que constitui o outro não como semelhante a si, mas como objeto propriamente ameaçador, do qual é preciso se proteger, desfazer ou simplesmente destruir (MBEMBE, 2018, p. 27-28). Ainda que o termo "raça" em si tenha sido cunhado na modernidade, ${ }^{7}$ a classificação hierarquizante de grupos humanos pela suposição de uma herança física e moral comum já era empreendida no ambiente mediterrânico desde muito tempo, tal como discursos sobre a dessemelhança perniciosa do outro.

Tendo em vista os parâmetros apresentados, é constatável a existência de discursos sobre raças nas comunidades cristãs mediterrânicas pós-constantinianas, em que saberes herdados de textos greco-latinos eram associados às demandas intelectuais cristâs. Segundo Isaac, autores antigos frequentemente justificavam a superioridade ou inferioridade de grupos humanos por características adquiridas por fatores climáticos e ambientais e transmitidas para as próximas gerações. Esses aspectos geograficamente determinados não diziam respeito apenas aos atributos fisionômicos, tendo em vista as relaçôes entre qualidades corporais e mentais; dessa maneira, os elementos climáticos incidiriam também sobre o caráter (ISAAC, 2004, p. 55-168). ${ }^{8}$ Entre autores cristáos, essas percepçóes seriam conciliadas com uma abordagem genealógica em que as características de cada grupo humano remontariam ao seu ancestral, presente nas Escrituras (BARTLETT, 2001, p. 43-46).9

A produção de discursos concernentes aos etíopes estaria relacionada a esses postulados raciais. Conforme já demonstrado por SNOWDEN (1970, p. 1-15), a pele negra, a mais destacada característica física dos etíopes, era consequência de fatores ambientais, principalmente o calor e a ação do sol. Entretanto, ao contrário do argumento de Snowden de que a diferença de cor era descrita de forma neutra, a explicação da diferença corporal era articulada a uma justificativa da inferioridade moral. Dados levantados na documentaçáo greco-romana apresentados por Gay Byron apontam para uma percepçáo negativa dos etíopes, principalmente pelos latinos: os etíopes e sua negritude eram evocados para simbolizar a feiura, o indesejável, a maldade e os comportamentos reprováveis (BYRON, 2002, p. 29-51).

\footnotetext{
${ }^{7}$ Os termos utilizados para se referir a sociedades diferentes eram genos e ethnos, em grego, e gentes e populus, em latim. Seus sentidos eram fluidos e variaram conforme a conjuntura (BARTLETT, 2001; GEARY, 2005 p. 57-80).

${ }^{8} \mathrm{O}$ tratado hipocrático Ares, águas e lugares, escrito por volta do século V antes da Era Comum, fazia a correlação entre elementos geográficos, aspectos corporais e qualidades morais. Após uma apresentação dos fundamentos teóricos de tais associaçóes, o autor descreve a influência do meio sobre povos diversos (HIPÓCRATES, 2005, p. 94-129). Deve-se frisar, aqui, a persistência do paradigma hipocrático ao longo de séculos.

${ }^{9}$ Os africanos eram considerados descendentes de Cam, o filho amaldiçoado de Noé (BARTLETT, 2001, p. 45).
} 
Segundo Pastoureau, na maioria das culturas antigas, a cor negra detinha um simbolismo ambivalente: por um lado, positivo, pois representava a fertilidade, tendo em vista ser o preto a cor da terra; por outro, negativo, estando associada à morte e à destruiçáo. Durante o Império Romano, a positividade atribuída à cor negra retrocede, dando-se maior ênfase aos seus aspectos negativos (PASTOUREAU, 2008, p. 20-35). Tendo em vista a correspondência entre atributos corporais e qualidades morais preconizada pelo saber fisiognômico clássico, ${ }^{10}$ a negritude da pele atestaria a imoralidade do etíope justamente pela negatividade da cor, principalmente na esfera da sexualidade (BRAKKE, 2001, p. 511-513).

Os autores cristãos articulariam tais referências anteriores a respeito dos etíopes em seus textos. Gay Byron demonstrou como o etíope era vinculado ao pecado, à heresia, à presença demoníaca e à tentaçáo sexual em escritos de autores como Orígenes, Agostinho, Jerônimo, dentre outros (BYRON, 2001, p. 55-121). David Brakke, por sua vez, analisou escritos monásticos dos séculos IV e V, concluindo que uma aparição de um negro etíope ante um asceta atestaria, pela forma, uma manifestação demoníaca e da incitação ao pecado, frequentemente o sexual (BRAKKE, 2001).

A procedência geográfica e os traços corporais eram marcos de dessemelhança que desqualificavam o outro nos textos clássicos; nos escritos do contexto do monaquismo emergente, a negatividade da diferença geográfica e física era indicativo indubitável de um inimigo a ser enfrentado pelo monge. É nesse sentido que defendo as potencialidades do recurso ao conceito de "raça" para a análise dos etíopes no discurso sobre o monaquismo emergente.

\section{A virtude da discretio em João Cassiano}

O termo latino discretio é comumente traduzido para o português como "discrição" ou "discernimento". Consiste numa adaptação da palavra grega diakrisis, utilizada para a atividade de distinguir entre duas coisas em contextos judiciais ou lógico-filosóficos (RICH, 2001, p. 1-2). Com os autores cristãos, difunde-se o emprego da expressão com sentidos espirituais. Nas traduçóes então disponíveis das Escrituras, havia certa recorrência do conceito de diakrisis/discretio, ${ }^{11}$ sendo a passagem de 1 Cor 12:20 a mais frequente no debate intelectual em curso até o século V (LIENHARDT, 1980, p. 508-511). De acordo com André Munzinger, a diakrisis penumaton na epístola paulina mencionada era apresentada como um

\footnotetext{
${ }^{10} \mathrm{~A}$ fisiognomia era um saber baseado na suposição de uma solidariedade entre alma e corpo, que permitiria avaliar, por meio dos indícios físicos e suas correlações morais, o caráter de alguém. A teoria tinha fundamentação médico-filosófica. Sobre a questão, conferir Magli (1991).

${ }^{11}$ Antony Rich empreendeu um levantamento quantitativo das ocorrências da diakrisis na Septuaginta e da discretio na Vulgata. Segundo os seus resultados, no Antigo Testamento, a diakrisis consta 25 vezes na Septuaginta e a discretio, cinco vezes na Vulgata. Quanto ao Novo Testamento, o autor apenas mencionou algumas passagens em que o termo aparecia na Vulgata (RICH, 2001, p. 2-11).
} 
dos dons concedidos por Deus, que habilitava o fiel a identificar a origem de manifestaçôes espirituais e de avaliar o seu sentido e significado (MUNZINGER, 2008, p. 101-140).

A trajetória do conceito foi minuciosamente estudada por outros autores, que interpretaram seus sentidos em obras como as de Orígenes e Evágrio Pôntico, ou em documentos como a Vita Antonii e os Apophthegmata Patrum (LIENHARDT, 1980; RICH, 2001; WORTLEY, 2011; DECOCK, 2013). Cabe aqui salientar o manejo da diakrisis/discretio na literatura monástica de maneira a reforçar o empenho do monge pelo aperfeiçoamento do controle de si, mesmo ante os assaltos das instigaçóes demoníacas. Entretanto, se até o início do século IV era o próprio sujeito que deveria realizar a identificação, a análise e o combate da influência externa de agentes maléficos, eventualmente a discretioldiscretio se transforma em atividade delegada ao outro. Conforme demonstrou Fabrizio Vecoli, a diakrisis/discretio paulatinamente se tornou mecanismo a partir do qual se fundamentava a subordinação ao outro. Tal processo acompanhou a promoção da hierarquização dos mosteiros e da autoridade ascética (VECOLI, 2009).

A produção intelectual de João Cassiano foi composta nesse contexto em que o conceito de discretio era manejado não mais para se referir ao empreendimento individual da ascese, mas à defesa da cessão plena de si a um superior como imprescindível à profissão monástica legítima. Além disso, suas posiçôes a respeito da vida monacal decorriam de sua inserção na correlaçáo de forças que perpassava a Gália naquele momento. Parcelas da aristocracia galo-romano avaliavam a adesáo ao monacato como uma alternativa viável de manter sua posição de elite num cenário repleto de adversidades (MATHISEN, 1994). Além de proporcionar uma nobilitas espiritual, relacionada ao cumprimento de valores cristãos (SALZMAN, 2001), o mosteiro se apresentava como etapa inicial de um cursus honorum de novo tipo, a partir do qual se poderia obter cargos nas estruturas eclesiásticas.

Dada a aproximação de Joâo Cassiano com esses segmentos abastados que ingressavam nos mosteiros, principalmente daqueles presentes na prestigiada comunidade de Lérins, a obra do marselhês proporcionava endosso teórico a tais aspiraçôes dessa elite. Assim, ao abordar a discretio, fundamentava tanto as pretensóes de afirmaçáo de grupos monásticos como uma elite ascética, quanto a legitimidade da autoridade daqueles oriundos do ambiente monástico.

O conceito de discretio perpassou as Coll. A primeira passagem em que João Cassiano abordou o tópico constava logo na primeira conferência, em que o abade Moisés esclarecia o fim e o escopo do monge. Ao discorrer sobre as cogitaçóes involuntárias e a capacidade humana de acolhê-las ou rejeitá-las, o conferencista elencava três possíveis origens para os pensamentos: divina, demoníaca ou humana. A discretio consistiria na competência de identificar a procedência, causa e autoria de cada pensamento e decidir como lidar adequadamente. Conviria ao monge que tal exame de si fosse incessante para prevenir o acesso dos vícios à alma (Coll. I, p. 98-105). 
$\mathrm{Na}$ Coll. II, o personagem do abade Moisés prosseguiria em sua exposiçáo sobre a discretio. Depois de indicar novamente a verificação constante dos pensamentos, o ancião acrescia outra dimensão à discretio: precaver a rigorosidade extrema na renúncia ascética. $\mathrm{Na}$ argumentação que sustentava essa orientação, era apontada a debilidade que poderia decorrer da privação excessiva, levando o monge a um estado de negligência e apatia - a abstenção extrema poderia ser tão nociva quanto a voracidade desmedida (Coll. II, p. 131-132). Portanto, o exercício da discretio deveria ter como diretriz a moderação (Coll. II, p. 131-134). Em consonância com a tradição pregressa, Joáo Cassiano reconhecia a discretio como um dom da graça divina, mas que caberia ao homem o empenho por alcançá-la. ${ }^{12} \mathrm{Na}$ narrativa da Coll. II, o abade Moisés alertava que todas as virtudes eram necessárias e úteis, mas apenas a discretio precaveria o monge de ser ludibriado e cair (Coll. II, p. 112-114). Ainda na mesma Coll., alegou que a discretio era a mãe, a guardiã e a moderadora de todas as virtudes (Coll. II, p. 116).

Todavia, a faculdade da discretio só poderia ser adquirida pelo aperfeiçoamento e pela formação na tradição dos "Pais", passíveis de obtidos por meio da vivência monacal genuína. ${ }^{13}$ João Cassiano caracterizava a ascese como uma perícia a ser adquirida por meio do esforço e de um processo de educaçáo pautada nos ensinamentos e exemplos dos Pais do Deserto (LEYSER, 2000, p. 33-61). Em diversas passagens, João Cassiano delimitava etapas sucessivas de progressão espiritual em que o monge avançaria na medida em que se aperfeiçoasse. ${ }^{14}$ Ao instituir a vida monástica como um percurso de desenvolvimento espiritual constante, o marselhês reconhecia a existência de desníveis de formação, de aperfeiçoamento e de mérito entre os monges. ${ }^{15}$

\footnotetext{
${ }^{12}$ João Cassiano se engajou na controvérsia sobre a graça divina desencadeada pelas teses formuladas por Pelágio, condenando a perspectiva pelagiana e se distanciando dos argumentos de Agostinho de Hipona a esse respeito. Sobre essa querela, conferir Weaver (1998).

${ }^{13}$ A menção aos "Pais" como modelos de perfeição monástica era algo recorrente em textos destinados aos monges. Assim, muitas vezes os autores apelavam à autoridade moral atribuída a esses personagens para justificar suas prescriçóes. Sobre esse tema, conferir Lenkaityté (2006, p. 261-262). Para uma análise mais detida sobre o uso que João Cassiano faz das alusôes aos "Pais", com ênfase na promoção da ideia de uma tradição, conferir Casiday (2008).

${ }^{14} \mathrm{Na}$ Coll. III, as modalidades de renúncia monacal foram divididas em três, sendo a última somente alcançável mediante a conquista das anteriores; na Coll. V, os vícios foram expostos pela ordem em que deveriam ser vencidos (Coll. V, p. 197-198); na Coll. X, apontava para dois passos sucessivos que seriam necessários para a obtenção da oração ininterrupta (Coll. X, p. 82-84); na Coll. XI, afirmou que havia três degraus para serem ascendidos no combate aos vícios (Coll. XI, p. 105-109); na Coll. XIV, João Cassiano descreveu uma jornada gradativa quanto ao conhecimento próprio da vida monástica (Coll. XIV, p. 183-184); na Coll. XXIV, eram apresentadas as três faculdades da alma - concupiscível, irascível e racional -, cada qual atormentada por um conjunto próprio de cogitaçóes, apresentadas na sequência da mais fácil para a mais difícil de lidar (Coll. XXIV, p. 186-187).

${ }^{15}$ Num dos capítulos da Coll. I, o autor comparou as prioridades de Marta e Maria: enquanto a primeira servia a Jesus e aos discípulos e se dedicava aos afazeres domésticos, a segunda se empenhava na contemplação divina. Deus demonstrou predileçáo por Maria, por estar num patamar de superioridade (Coll. I, p. 87). A passagem exemplifica a articulação entre progressão espiritual e desigualdade de méritos.
} 
O princípio da desigualdade de progressáo espiritual entre os monges era o que fundamentava a autoridade na obra de Joáo Cassiano: os novatos, por falta de perícia na ascese e ciência da tradição, não estariam aptos a exercer a discretio por eles mesmos, devendo ser humildes, pacientes e obedientes para se subordinarem à discretio de um ancião. A cessão de si deveria ser perpétua, pois a obediência deveria seguir por toda a vida, e plena, com o jovem asceta jamais confiando em seu próprio juízo e sempre revelando os seus pensamentos a um anciāo. ${ }^{16} \mathrm{~A}$ articulação entre discretio, desnível espiritual e saber sobre os preceitos dos "Pais" respaldava a distinção aspirada pelos grupos monásticos, a autoridade dos monges que ascendiam na hierarquia eclesiástica e a condenação de facçôes clericais que não se adequassem a esses princípios (LEYSER, 2000, p. 33-61).

\section{Etíopes e discretio nas Coll.}

Nas Coll., há três ocasiōes em que constam menções a etíopes, todos referidos como demônios: no capítulo XXI da Coll. I, no capítulo XIII da Coll. II e no capítulo VI da Coll. IX. A seguir, apresento cada narrativa, relacionando-a ao debate realizado em cada Coll.

A primeira referência a um etíope no documento consta logo na primeira Coll., em que foram atribuídos ao abade Moisés ensinamentos sobre o escopo e o fim da vida monacal. No decorrer da conferência, o personagem abordou a orientação em que os monges deveriam perseverar para obter aquilo que seria sua intenção: o reino dos céus. No capítulo XVI, Germano perguntou sobre a possibilidade de o monge conseguir se libertar da perturbaçáo de pensamentos sutis e súbitos contrários à vontade. O abade Moisés, então, discorreu sobre os temas da mobilidade da alma, das cogitaçôes e da discretio nos capítulos restantes da Coll.

Portanto, a menção a um negro etíope no capítulo XXI integrava uma discussão concernente à necessidade da discretio ante o inevitável fluxo de pensamentos involuntários. No episódio, narrava-se a entrega de João de Lico a uma abstinência desmedida em função de uma instigação demoníaca:

Desse modo, como soubemos há pouco, é que foi enganado o abade Joáo, residente em Lico. Com o corpo exausto e alquebrado, retardou por dois dias, indevidamente, sua refeição. No dia seguinte, quando enfim se dispunha a tomar algum alimento, o diabo, sob a aparência de um hediondo etíope, lançou-se aos seus joelhos, dizendo: "perdáo, fui eu que te impus esse sofrimento" (Coll. I, p. 105). ${ }^{17}$

\footnotetext{
${ }^{16}$ João Cassiano prescrevia a prática da confissão ante um superior, portanto. Tal encaminhamento se encontra desenvolvido, sobretudo, em: Coll. II, p. 120-130.

${ }_{17}$ Tradução da Subiaco, com correçôes minhas. No original: "In quo etiam abbatem Iohannem, qui Lyci commoratur, nouimus nuper inlusum. Nam cum exhausto corpore atque defecto perceptionem cibi biduano ieiunio distulisset, accedenti ei ad refectionem die póstero ueniens diabolus in figura Aethiopis tetris atque ad eius genua prouolutus, indulge, inquit, mihi, quia ego ti hunc laborem indixi".
} 
$\mathrm{Na}$ sequência, evocaram-se as virtudes de João de Lico e sua competência em identificar que incorrera num jejum exagerado pela artimanha de um demônio, que o iludiu acerca da legitimidade de tal prática:

Assim, aquele grande varão, tão perfeito no que diz respeito à virtude da discretio, reconheceu que, a pretexto de uma imprudente abstinência, fora surpreendido pela astúcia do demônio e se deixara exaurir por um jejum que enfraquecera seu corpo, já esgotado por uma estafa desnecessária e, pior ainda, prejudicial a seu espírito. Ludibriado por uma moeda falsa, venerou a imagem do rei verdadeiro, sem examinar, suficientemente, a legitimidade da cunhagem (Coll. I, p. 105$).^{18}$

$\mathrm{Na}$ passagem, exaltou-se a competência do personagem no reconhecimento da inclinação maligna que o levou ao jejum desnecessariamente debilitante, logo prejudicial. João de Lico conheceu a procedência da cogitação pelo ato de contrariá-la: comeu, quando era incitado à abstinência, levando o demônio a revelar a sua presença e a sua armadilha; mas a natureza perniciosa de quem o instigara era indicada apenas pela sua aparência medonha e etíope.

Outra alusão a um etíope figurou na Coll. II, cujos ensinamentos eram novamente atribuídos ao abade Moisés. Conforme referido anteriormente, o tema da conferência era a discretio, sendo apresentadas sua definição conceitual e suas implicaçôes na vida monacal. A aparição do demônio etíope foi narrada no capítulo XIII, após ser postulada a necessidade de se expor todos os pensamentos a anciôes bem-formados e de conduta exemplar. Nesse capítulo em particular, alertava-se que nem todos os anciōes eram virtuosos e bem-formados, não sendo apropriado aos monges seguir o exemplo ou acolher os conselhos e ensinamento de qualquer um de vasta idade. A ressalva estava em consonância com a fundamentação teórica da autoridade ascética legítima que perpassava a obra de João Cassiano, que tinha o domínio da perícia espiritual e a formaçáo adequada como crivos para a liderança monacal autêntica.

O acometido pela instigação demoníaca não é nomeado no texto, sendo descrito apenas com "um jovem, que não era dos menos fervorosos"19 (Coll. II, p. 124). Segundo o relato, o monge, buscando progredir e se curar dos seus males, confessou a um ancião que estava sob o tormento do espírito de fornicação, sendo duramente repreendido. Como resultado da condenação pelo ancião, o jovem, acometido pelo desespero e pela tristeza, abandonou a cela e cogitou satisfazer sua concupiscência. Ao encontrar o abade Apolo e contar a ele todo

\footnotetext{
${ }^{18}$ Tradução da Subiaco, com correçóes minhas. No original: "Itaque ille uir tantus et in discretionis ratione perfectus sub colore continentiae incongruenter exercitae intellexit se ob hoc calliditatate diaboli circumuentum talique distentum ieiunio, ut lassitudinem no necessariam, immo etiam spiritui nocituram fatigato corpori superponeret, paracharaximo scilicet inlusus nomismate, dum in illo ueri regis imaginem ueneratus parum discutit na esset legitime figuratum".

${ }^{19}$ Tradução da Subiaco. No original: "[...] non ignauissimorum iuuenum profectus".
} 
o ocorrido, o monge novato foi consolado e recebeu, enfim, palavras de compaixão e o conselho de náo se abater pela violência das tentaçôes - assédio a que todos estariam submetidos (Coll. II, p. 125-127).

Após consolar o rapaz, Apolo foi ao mosteiro do ancião repreensor e pôs-se a rezar diante dele. Em sua prece, pediu a Deus que fizesse com que a tentação do jovem acometesse o ancião sem compaixão, para que aprendesse a ser condescendente com a fraqueza alheia e misericordioso com a fragilidade dos mais novos. É nesse momento que surge o demônio:

Mal terminara essa oração, a gemer, que se deparou com um horrendo etíope de pé, diante da cela do anciáo, atirando contra ele dardos de fogo. Atingido por eles, saiu o anciáo de sua cela e, como um ébrio ou alguém que perdeu a razão, começou a correr em todas as direçóes. Entrando e saindo, sem poder permanecer na cela, tomou apressadamente o mesmo caminho por onde saíra aquele jovem. Quando o abade Apolo o viu como um demente ou um homem que parecia atingido pelas Fúrias, compreendeu que o dardo inflamado que vira na mão do demônio penetrara-lhe o coração, causando-lhe toda aquela perturbação dos sentidos e confusão da mente (Coll. II, p. 127). ${ }^{20}$

Deve-se destacar a conjugação entre o aspecto horrendo e a procedência etíope como elemento que torna o ser identificável como demônio, tal como a chama dos dardos identificava a instigação concupiscente. Embora não esteja explicitada, há um vínculo entre a forma em que se apresenta a figura demoníaca e o tormento específico a que os monges são submetidos na narrativa: o espírito da fornicação.

Após a transferência da tentação do jovem para o ancião sem compaixão, abade Apolo indagou ao perturbado pela incitação da concupiscência o porquê de estar agitado. Tendo como resposta o silêncio, retorna a falar com o anciáo em agito, apontando-lhe que, após longo tempo sendo ignorado ou desprezado pelo demônio, não teve êxito em lidar com o assalto maligno. Apolo explicou que a ausência de mérito espiritual do ancião em agito pelos dardos ardentes era a razão de ter sido negligenciado pelas forças demoníacas. Ao findar sua lição e apelar ao ancião que fosse mais compreensível com os mais jovens e frágeis, o abade Apolo ora novamente pedindo a Deus que livrasse o ancião da tentação (Coll. II, p. 127-129).

$\mathrm{Na}$ narrativa, quem consegue identificar a origem e a natureza da inclinaçâo para a fornicação não foi o ancião que não progredira, mas o abade Apolo - que o fez pela aparência $\mathrm{e}$ pela etiopicidade do demônio que visualizou. Quem obteve a vitória sobre a cogitaçáo malig-

${ }^{20}$ Tradução da Subiaco. No original: "Cumque ille hanc precem cum gemitu conclusisset, cernit Aethiopem tetrum contra illius cellulam stantem atque ignita aduersus eum iacula dirigentem. Quibus cum fuisset ille protinus sauciatus et progressus e cella buc illucque uelut amens et ebrius cursitaret, atque egrediens et ingrediens iam se in ea continere non posset, eadem uia perfere concitus coepit, qua iunenis ille discesserat. Quem abbas Apollo uelut amentem factum quibusdam furiis conspiciens agitari intellexit ignitum diaboli quod uiderat telum in corde eius fuisse defixum illamque in eo confusionem mentis ac perturbationes sensuum intolerandis aestibus operari". 
na foi igualmente o abade Apolo, aquele para quem a revelação dos pensamentos resultou no reconhecimento da malignidade do instigador e a possibilidade de afastá-lo. Portanto, nesse episódio, a tópica racial foi evocada num enredo de maneira a enfatizar que apenas Apolo detinha a discretio e, portanto, era o único efetivamente apto à direção pastoral dos novatos.

A última menção a um demônio etíope consta na Coll. IX, conferência atribuída ao abade Isaac e que versava sobre a oração contínua. O capítulo VI dessa Coll. encerra definindo tudo que excede às necessidades cotidianas e às exigências do corpo como preocupaçôes mundanas que afastariam a alma de Deus. No capítulo seguinte, em que figura o demônio etíope, é narrado o caso de um monge que se entregou desmedidamente a um trabalho físico.

Segundo o relato, um monge se dedicava à construção e ao reparo de coisas supérfluas com afinco demasiadamente fatigante. Um ancião que passava em frente à sua cela o observou quebrando um bloco de pedra duríssimo com um martelo muito pesado. Contudo, o idoso também percebeu que havia, ao lado do monge laborioso, um etíope com as mãos entrelaçadas com as dele, ajudando-o com as marteladas e instigando-o ao trabalho com tochas de fogo; quando o asceta buscava descansar, o demônio forçava-o a empunhar novamente o martelo e retornar urgentemente à atividade (Coll. IX, p. 45-46).

No relato, novamente a etiopicidade do personagem foi atrelada à sua natureza demoníaca, tal como o fogo explicitava a malignidade da instigaçáo que fomentava no atormentado. A trama se concluía com o anciáo interpelando o monge:

Então, profundamente emocionado pelo cruel embuste do demônio, o ancião, desviando-se de seu caminho, vai até a cela do irmão e saudando-o lhe diz: "Que tipo de trabalho é esse que está fazendo?" E o irmão responde: "trabalhamos neste bloco de pedra duríssimo, e foi com imenso esforço que pudemos parti-lo". E o anciáo, em resposta: “bem disseste 'pudemos' pois não o partiste sozinho, contigo estava um outro a quem não viste. E que, neste trabalho, não só te ajudava como também com a maior violência te instigava a prossegui-lo" (Coll. IX, p. 46). ${ }^{21}$

Nesse desfecho, evidencia-se que apenas o anciáo conseguia ver o etíope, a despeito deste permanecer todo o tempo ao lado do monge. Apesar do cerne da questáo nesta passagem náo serem as relaçóes de poder, mas os entraves da mundanidade à contemplação, a apresentação do ancião como único apto a ver o demônio retifica a desigualdade de méritos e a necessidade de subordinação à discretio alheia.

Dos três episódios analisados, apenas o primeiro deles é que o próprio personagem percebeu a presença demoníaca que o instigava ao erro; porém, João de Lico é apresentado

\footnotetext{
${ }^{21}$ Tradução da Subiaco. No original: "Tandem igitur senex tam dirá daemonis ludificationes permotus ad cella fatris diuertit salutansque eum, quod, inquit, est frater, istud opus quod agis? At ille: Laboramus, ait, contra istud durissimum saxum uixque illud potuimus aliquando conterere. Ad haec senex: Bene dixisti 'potuimus'. Non enim solus eras, cum illud caederes, sed fuit alius tecum quem non uidisti, qui tibi in hoc opere non tam adiutor quam uiolentissimus impulsor adstabat".
} 
como alguém virtuoso e que consegue tal feito justamente em função de seus méritos. Nos outros dois casos, foram anciōes que constataram o fomento demoníaco de um etíope, não o próprio monge. A negritude não constava em nenhuma das histórias, constando, entretanto, qualificaçóes negativas a respeito da fisionomia do etíope.

Em cada um dos casos, a alusão à etiopicidade da aparição diabólica ocorre apenas uma vez, sem ser acompanhada de reflexóes que justificassem o vínculo entre o demoníaco e a procedência etíope. Não há, no decorrer das Coll., mençóes à região da Etiópia, tampouco a acontecimentos, pessoas ou grupos de lá. A qualificaçáo dos demônios como especificamente etíope decorria da negatividade e da periculosidade entáo amplamente atribuídas aos pertencentes a essa raça. Nesse sentido, João Cassiano empregou nas três passagens uma retórica etnopolítica (BYRON, 2001), em que o tropo da diferença do outro distante era articulado não contra uma comunidade externa, mas em favor das ideias que pretendia promover como ortodoxas no âmbito da própria comunidade a que pertencia.

\section{Conclusóes}

João Cassiano se estabeleceu definitivamente na região da Gália no começo do século V, após enfrentar longo percurso desde sua saída do seu mosteiro em Belém. Foi nesse momento em que escreveu as Coll., conjunto de livros sobre a vida monacal compostos na forma de diálogos. Nesse material, perpassava a ideia de que a discretio, aptidão da relação adequada com as cogitaçôes involuntárias e com a moderação ascética, era a virtude imprescindível à progressão espiritual e ao controle de si.

As Coll. foram redigidas num contexto mediterrânico em que circulavam, desde antes da emergência do monaquismo ou mesmo do cristianismo, discursos raciais - ou seja, que classificavam grupos humanos a partir de supostas essências fisionômicas e morais decorrentes de sua origem e da transmissão de características entre geraçôes. Naquele contexto, afirmava-se que a dessemelhança do outro distante, decorrente da sua procedência geográfica, estaria atrelada a uma inferioridade moral atestada pelas diferenças do seu corpo. O etíope, por ser o mais negro e remoto dos homens, era caracterizado por uma série de atributos negativos, particularmente no que tange à esfera da sexualidade. Na literatura ascética produzida na época de emergência do monaquismo cristão, figuravam demônios que apareciam como etíopes atentando contra a virtude do monge, ratificando a noçâo de negritude do etíope como indicativo de perniciosidade.

João Cassiano escreveu as Coll. tendo em vista um segmento da elite galo-romana em dificuldades que aderia ao monacato como forma de distinção e de cursus honorum viável. A maneira como discorreu sobre a vida monacal propiciava respaldo teórico às aspiraçóes de grupos monásticos e clericais por prestígio e por autoridade legítima. A discretio, concerne à 
aptidão para identificar a origem e a natureza dos pensamentos involuntários e para praticar uma ascese adequada, era evocada para sublinhar o mérito monástico no esforço de progressão e para justificar a subordinação plena dos mais novos aos anciōes.

Todas as passagens em que constavam alusóes a etíopes no documento analisado estavam associadas ao exercício da discretio por parte de abades bem-formados e aperfeiçoados, jamais de monge jovem e inexperiente. Nos episódios narrados, demônios instigadores do pecado eram identificados enquanto tais por se apresentarem na forma de um etíope. A conjunção entre procedência geográfica e aspectos físicos era o indicativo de uma essência perversa e infernal. A presença negativa do etíope nas Coll. não era direcionada à Etiópia ou aos etíopes propriamente ditos, mas era parte de uma retórica que evocava um tropo racial consolidado em favor da promoção de determinado perfil monacal.

\section{Fontes documentais}

JOÃO CASSIANO. Conférences. Paris: Éditions du Cerf, 1959. 3v.

JOÃO CASSIANO. Conferências. Juiz de Fora: Subiaco, 2011. 3v.

HIPÓCRATES. Ares, águas e lugares. In: HIPÓCRATES. Textos hipocráticos: o doente, o médico e a doença. Rio de Janeiro: Fiocruz, 2005. p. 94-129.

\section{Referências}

BARTLETT, Robert. Medieval and modern concepts of race and ethnicity. Journal of Medieval and Early Modern Studies, v. 31, n. 1, p. 39-56, 2001.

BEARDSLEY, Grace H. The ethiopian in greek and roman civilization. Tese (Doutorado em Filosofia), Johns Hopkins University, 1922.

BRAKKE, David. Ethiopian demons: male sexuality, the black-skinned other, and the monastic self. Journal of the History of Sexuality, v. 10, n. 3, p. 501-535, 2001.

BUELL, Denise K. Rethinking the relevance of race for Early Christian self-definition. Harvard Theological Review, v. 94, n. 4, p. 449-476, 2001.

BYRON, GAY L. Symbolic blackness and ethnic difference in early christian literature. London, New York: Routlegde, 2002.

CASIDAY, Augustine. Tradition as a governing theme in the writings of John Cassian. Early Medieval Europe, v. 16, n. 2, p. 191-214, 2008.

DECOCK, Paul B. Discerniment in Origen of Alexandria. Acta Theologica Supplementum, n. 17, p. 189-208, 2013. 
FREDRISON, George M. Racism. A short history. Princeton: Princeton University, 2002. BETHENCOURT, Francisco. Racismos. Das Cruzadas ao século XX. São Paulo: Companhia das Letras, 2018.

GUIMARÃES, Antonio Sérgio Alfredo. Como trabalhar com "raça” em sociologia. Educação e Pesquisa, v. 29, n. 1, p. 93-107, 2003.

HAHN, Thomas. The difference the Middle Ages makes: color and race before the modern world. Journal of Medieval and Early Modern Studies, v. 31, n. 1, p. 1-38, 2001.

HENG, Geraldine. The invention of race in the european Middle Ages. Cambridge: Cambridge University, 2018.

ISAAC, Benjamin. The invention of racism in classical Antiquity. Princeton: Princeton University, 2004.

LENKAITYTÉ, Manté. Patris nostri. Présence des Pères dans les règles monastiques anciennes d'Occident. Revue d'Études Augustiniennes et Patristiques, n. 52, p. 261-285, 2006. p. 261-262.

LEYSER, Conrad. Authority and ascetiscim from Augustine to Gregory the Great. Oxford: Oxford University, 2000.

LIENHARD, Joseph T. On "discernment of spirits" in the Early Church. Theological Studies, v. 41, n. 3, p. 505-529, 1980.

MATHISEN, Ralph W. The ideology of monastic and aristocratic community in Late Roman Gaul. Polis, n. 6, p. 203-220, 1994.

MBEMBE, Achille. Crítica da razão negra. São Paulo: N-1, 2018.

MUNZINGER, André. Discerning the spirits. Theological and ethical hermeneutics in Paul. Cambridge: Cambridge University, 2007.

PASTOUREAU, Michel. Black. The history of a color. Princeton: Princeton University, 2008.

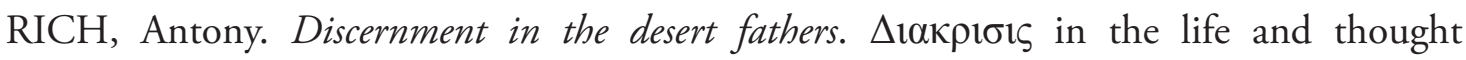
of early egyptian monasticism. Bletchley: Paternoster, 2007

SALZMAN, Michele. Competing claims to "nobilitas" in the Western Empire of the fourth and fifth centuries. Journal of Early Christina Studies, v. 9, n. 3, p. 359-385, 2001.

SAMUELS, Tristan. The riddle in the dark. Re-thinking "blackness" in greco-roman racial discourse. Tese (Doutorado em Filosofia). Universidade de Toronto, 2013.

SNOWDEN, Frank M. Blacks in Antiquity. Ethipians in the Greco-Roman Experience. Cambridge: Harvard University, 1970.

STEWART, Columba. Cassian the monk. New York, Oxford: Oxford University, 1998.

VECOLI, Fabrizio. Transformazione del discernimento in pratica istituzionale nella 
tradizione egiziana. Rivista di Storia del Cristianesimo, v. 6, n. 1, p. 21-40, 2009.

WEAVER, Rebecca Harden. Divine grave and human agency. A study of semi-pelagian controversy. Macon: Mercer University, 1998.

WORTLEY, John. Discretion: greater than all the virtues. Greek, Roman, and Byzantine Studies, n. 51, p. 634-652, 2011.

DENCH, Emma. Romulus' Asylum. Roman identities from the Age of Alexander to the Age of Hadrian. Oxford: Oxford University, 2005.

MAGLI, Patrizia. El rostro y el alma. In: FEHER; M.; NADDAFF, R.; TAZI, N. (eds.). Fragmentos para una historia del cuerpo humano. Madrid: Taurus, 3v. v. 2, 1991. p. 87-127. GEARY, Patrick J. O mito das naçôes: a invenção do nacionalismo. São Paulo: Conrad, 2005. 